\title{
Effects of Prenatal Tobacco Smoke on Cerebellum Histomorphological Changes at Critical Developmental Stages in CD-1 Mice
}

\author{
Efectos del Humo de Tabaco en los Cambios Histomorfológicos del \\ Cerebelo en las Etapas Críticas del Desarrollo Prenatal en Ratones CD-1
}

Issa S. Al-Amri'; Isam T. Kadim ${ }^{1}$; Abdulaziz Alkindi'; Samera K. Khalaf ${ }^{2}$; Ahmed Hamaed ${ }^{1}$; Sausan S. Al- Yaqoobi²; Ahmed S. Al-Harrasi ${ }^{2}$; Sulaiman A. Al-Hashmi ${ }^{2}$, Ahoud A. Al-Maasbi ${ }^{1}$; Raqiya S. Al-Harthy ${ }^{1}$; Amira S. Al-Shabibi ${ }^{1}$ \& Asala I. Al-Amri ${ }^{1}$

AL-AMRI, I. S.; KADIM, I. T.; ALKINDI, A.; KHALAF, S. K.; HAMAED, A.; AL- YAQOOBI, S. S.; AL-HARRASI, A. S.; ALHASHMI, S. A.; AL-MAASBI, A. A.; AL-HARTHY, R. S.; AL-SHABIBI, A. S. \& AL-AMRI, A. I. Effects of prenatal tobacco smoke on cerebellum histomorphological changes at critical developmental stages in CD-1 mice. Int. J. Morphol., 39(1):318-326, 2021.

SUMMARY: In this study the consequences of prenatal exposure to tobacco smokes on the histo-morphological changes of cerebellum was assessed by comparing the smoker mice to the nonsmoker mice. A total of 30 pregnant cd- 1 mice were divided into three groups of 10 mice each and with two replicates per group (5 mice each). Following acclimation for five days, the mice were placed in a special modified smoking machine for 2 hours per day over a two- and three-week period for group two and group three, respectively. Group one was considered as a control group. Mice in the control group were exposed simultaneously to fresh air from the room, while those in the treatment groups were exposed to tobacco smoke from six commercial filter cigarettes, containing $0.8 \mathrm{mg}$ of nicotine, $10 \mathrm{mg}$ of tar, and $10 \mathrm{mg}$ of carbon monoxide, for three 1-hour exposure periods every day for three weeks. The mice in the control group were exposed to room air for three 1-hour periods every day for the same period of three weeks. The results from this study showed a correlation between maternal smoking and histological changes in Neuron purkinjense (Purkinje cells) of the cerebellum. They also showed that prenatal smoking period may have caused more damage in the histology and structure of Neuron purkinjense in some juvenile mice. An increased incidence of morphology damage of the cerebellum's Neuron purkinjense' structures was also observed in fetuses with prolonged exposure to tobacco smoking. Exposure of in utero maternal smoking may interfere with brain biological development parameters, giving rise to structural abnormalities of the cerebellum. This study concluded that tobacco smoke exposure to pregnant mice may affect neurodevelopment which may induce behavioural changes as a result of reduced cerebellar size and function.

KEY WORDS: Prenatal tobacco smoke; Cerebellum; Histomorphology; CD-1 mice; Purkinje cells; Neuron purkinjense; Juvenile.

\section{INTRODUCTION}

Although tobacco smoking is recognized as a risk factor for negative health outcomes, which include cancer, chronic lung disease and increased rates of heart disease, the daily smoking of tobacco has been increasing rapidly all over the world (Musk \& de Klerk, 2003; Hecht et al., 2005; Benowitz et al., 2007; Stepanov et al., 2008). Tobacco smoke contains both organic and inorganic carcinogenic compounds. The chemical compositions of tobacco smoke are one of the major causes of morbidity and mortality in the world (Stolerman \& Jarvis, 1995). Approximately, 4000 chemical compounds were identified in tobacco smoke and the majority of them are very harmful and toxic for human health (Fuller et al., 2010). The majority of these toxic compounds are nicotine, polycyclic aromatic hydrocarbons and heavy metals. The relatively high rate of tobacco smoking among pregnant women ( $25 \%$ of all pregnancies) underlines the seriousness of these concerns, therefore the negative consequences are compounded when the smoker is a pregnant mother (Cornrlius \& Day 2009). Prenatal tobacco exposure is strongly associated with hazardous effects on overall health and development of the infant (Bhutta et al., 2010). Smoking during pregnancy leads to premature rupture of membranes, placental abruption, preterm delivery, intrauterine growth restriction and an

\footnotetext{
${ }^{1}$ Department of Biological Sciences and Chemistry, College of Arts and Sciences, Sultanate of Oman.

${ }^{2}$ Natural and Medical Sciences Research Center, University of Nizwa, PO Box 33, PC 616, Birkat Al-Mouz, Nizwa, Sultanate of Oman.
} 
AL-AMRI, I. S.; KADIM, I. T.; ALKINDI, A.; KHALAF, S. K.; HAMAED, A.; AL- YAQOOBI, S. S.; AL-HARRASI, A. S.; AL-HASHMI, S. A.; AL-MAASBI, A. A.; AL-HARTHY, R. S.; ALSHABIBI, A. S. \& AL-AMRI, A. I. Effects of prenatal tobacco smoke on cerebellum histomorphological changes at critical developmental stages in CD-1 mice. Int. J. Morphol., 39(1):318-326, 2021.

increased risk of sudden fetus death syndrome (Steyn et al., 2006; Bhutta et al,). Prenatal tobacco exposure affects the growing fetus through the nicotine that crosses the placenta and gets concentrated in the fetal tissue and then affects the growth and development of the fetus through placental pathology (Cornelius \& Day, 2009). Moreover, prenatal tobacco exposure is harmful to the fetus brain, including impaired immune function and structural deficiencies in brain volume (Bhutta et al.). It might also cause deficit in growth and neural development of the cerebellum of the brain which has many effects on its function, cognition, and behavior (Roy et al., 2002; Hermann et al., 2008; Cornelius \& Day).

The addiction to the nicotine during pregnancy has enormous implications on the fetus and on the newborn baby (Galazyn-Sidorczuk et al., 2008). Tobacco contains, approximately, 8-9 mg of nicotine (Erzen \& Kragelj, 2006) which exceeds the permissible limit. At the same time, toxic heavy metals such as cadmium, chromium, lead and nickel also found in tobacco smoke and are accumulating in tissues and fluids, which may lead to kidney damage, fragile bones and cancer (Fowles \& Dybing, 2003; Massadeh et al., 2005; Pappas et al., 2007; Viana et al., 2011).

Epidemiological studies show that human exposure to tobacco smoke is usually associated with an increased risk of cancer and neurodevelopment. Across large parts of the Middle East over $50 \%$ of fetus, infants and babies are regularly exposed to tobacco smoke. The cerebellum precedes most brain structures. The cerebellum is essential for normal neurodevelopment and is particularly susceptible for intra-uterine disruptions. Researchers showed that a steep growth curve during fetal life will lead to an increase of up to $500 \%$ in cerebellar volume during the second and third trimesters of gestation (Chang et al., 2000; ten Donkelaar et al., 2003; Limperopoulos et al., 2005). The cerebellum phylogenetically is imitative from the metencephalon, a subdivision of the rhombencephalon and embryologically from the dorsal thickenings of the alar plates (Imosemi, 2013). In mice, most Neuron purkinjense (Purkinje cells) originate from the cerebellar anlage by day 15 of development (Altman \& Bayer, 1978). The Neuron purkinjense migrate through the deep nuclear neuropil at birth; accumulate in a layer deep to the external granular layer (EGL) (Altman \& Bayer). By the first few days of post-partum, Neuron purkinjense have assembled into a mono layer (Altman \& Winfree, 1977). Climbing fibers, which are excitatory fibers from the inferior olivary nucleus, become functional at early age and engage many Neuron purkinjense (Crepel, 1971; Mariani, 1982). Therefore, the cerebellum functions in controlling various motor activities in the brain. It also controls the range, distance and amplitude of voluntary muscles activity. It is the integrating center for willed muscular movements and posture. It plays an important role in the production of smooth words and for precise and intrinsic movements (Hendelman, 2000). Harmful tobacco exposures during pregnancy may pose a risk to disrupt prenatal cerebellar development (Shevelkin et al., 2014). Therefore, the objective of the present study is to investigate the effects of prenatal tobacco exposure on the histological changes in the cd-1 mice cerebellum at some critical developmental stages.

\section{MATERIAL AND METHOD}

Standard research grade cigarettes were purchased and stored in the laboratory at room temperature $\left(22-24^{\circ} \mathrm{C}\right)$ before processing.

Mouse study. Thirty pregnant CD-1 mice, of 7 months of age and weighing between 30 and $35 \mathrm{~g}$, were divided into three groups of 10 mice each (two replicate per group with 5 mice each) and housed in a small animal facility at University of Nizwa on a 12-hour light cycle with access to ad libitum food and water. The pregnant mice were acclimated to the laboratory for five days. Following acclimation, mice were placed in a special modified smoking machine for two hours per day over a three-week period for the control group (group one), while for group two they were carried out for the same three-week period but exposed to tobacco smoking for one week. The third group was carried out for the same three-week period but exposed to tobacco smoking for two weeks. Mice in the control group were exposed simultaneously to fresh air from the room. Mice in groups two and three were exposed to tobacco smoke from standard research grade cigarettes containing $0.8 \mathrm{mg}$ of nicotine, $10 \mathrm{mg}$ of tar, and $10 \mathrm{mg}$ of carbon monoxide (CO), for two one-hour exposure periods (from 8:00 a.m. to 9:00 a.m. and from 12:00 p.m. to 1:00 p.m.) every day for three weeks. During each exposure period, the mice in the tobacco smoke group were exposed to smoke from 6 tobacco cigarettes for $15 \mathrm{~min}$, the smoking apparatus was set to cycle with cigarette-suction periods of 10-s and rest periods of 15-s, followed by a 5min rest period during which room air was delivered to prevent hypoxia. Group two and three were exposed to a mixture of $15 \%$ mainstream (aspirated through filter) and $85 \%$ side stream smoke diluted with air to a concentration of $3 \mathrm{mg} / \mathrm{m}^{3}$ of repairable suspended particulate. During each exposure, tobacco cigarettes were smoked at a rate of one puff per minute, two second per puff $\left(35 \mathrm{~cm}^{3}\right)$, for eight puffs in nine min per cigarette. This model provided comparable air-born exposure as experienced in a $50-\mathrm{m}^{3}$ 
AL-AMRI, I. S.; KADIM, I. T.; ALKINDI, A.; KHALAF, S. K.; HAMAED, A.; AL- YAQOOBI, S. S.; AL-HARRASI, A. S.; AL-HASHMI, S. A.; AL-MAASBI, A. A.; AL-HARTHY, R. S.; ALSHABIBI, A. S. \& AL-AMRI, A. I. Effects of prenatal tobacco smoke on cerebellum histomorphological changes at critical developmental stages in CD-1 mice. Int. J. Morphol., 39(1):318-326, 2021.

household room (0.7 air changes per hour), with a smoker consuming two tobacco cigarettes per hour over $10 \mathrm{~h}$, which was validated by repeated mass measurements of repairable suspended particles.

The apparatus consists of a mice containment system and a tobacco smoking device. The mice cage $(24 \mathrm{~cm} \times 17$ $\mathrm{cm} \times 15 \mathrm{~cm}$ ) closed at the top. Two apparatuses were used in the present study: one for the animals in the tobacco smoke group and one for the animals in the control group. The tobacco smoke delivery system consisted of an external tobacco holder connected to a dynamic suction pump by a flexible hose. The pump was programmed to alternate between periods of tobacco suction and periods of clean air suction, to prevent asphyxia. The pump generates negative pressure, which forces the air through a lit-up cigarette, generating tobacco smoke pushing it toward the hose and into the acrylic box. A day after the last exposure, mice were decapitated under deep anesthesia ( $5 \%$ isoflurane for five min). The frontal cortex, hippocampus and cerebellum were dissected using stereomicroscope and then immersed in 10 $\%$ formaldehyde solution.

Histology. Samples from cerebellum were fixed in $10 \%$ formaldehyde and processed using Automated Tissue Processer machine (ATP 140). In the process tissues were dehydrated by graded concentrations of ethanol of $70 \%$ and $90 \%$ for 1 hour each, and three changes of $100 \%$ ethanol for 1,2 and 2.5 hours respectively. Tissues were then cleared with three changes of xylene of 1,1 and 2 hours respectively, then infiltrated in three changes of melted paraffin wax at $60 \mathrm{oC}$ for 1 hour each. Samples were then embedded in pure paraffin wax using Embedding Center Machine (AEC 380). Paraffin blocks were sectioned by Rotary Microtome (AEM $450)$ in order to produce thin sections of $5 \mu \mathrm{m}$ thickness.

Sections were collected with glass slides and placed on a hot plate. Sections were then placed in xylene for two times of 5 minutes each to remove the wax, hydrated in two changes of $100 \%$ alcohol of 5 minutes each, then $95 \%$ ethanol and $70 \%$ ethanol for 2 minutes each and finally in distilled water for 2 minutes. Each section was stained with Hematoxylin and Eosin and dehydrated with $95 \%$ alcohol (3-5 dips), two changes of $100 \%$ alcohol for 2 minute each and then cleared with xylene for 5 minutes. Finally, slides were mounted with DPX and cover slip and screened under light microscope.

\section{RESULTS}

Histological examination performed on cerebellum serial section demonstrated that morphological details of the cerebellum tissue consisting of white and gray matters. The brain tissues from the three mice groups were compared for morphological changes in relation to structural changes in the brain neurons, practicality the Neuron purkinjense (multipolar neuron) located in the gray matter of the cerebellum. In the control group, tissues from the cerebellum showed a normal representation of white matter and grey matter as shown in Figure 1. The grey matter located in the cortex consists of three layers: granular layer, Purkinje cell layer (PL) and molecular layer (Fig. 1B). The white matter located in the medulla consists mainly of neuroglia cells. The grey matter consists of nerve cells which includes neurons and neuroglia cells. The neurons related to Neuron purkinjense are located in the PL. The general structural organization of the cerebellum tissue appeared normal as shown in Figure 1. There was no damage detected in the morphology of this tissue. The morphology of Neuron purkinjense in the grey matter also appeared normal. The neurons consist of cell body (soma), multiple dendrites and an axon. The shape of soma appeared round with a large nucleus containing a single nucleolus in the center (Fig. 1C).
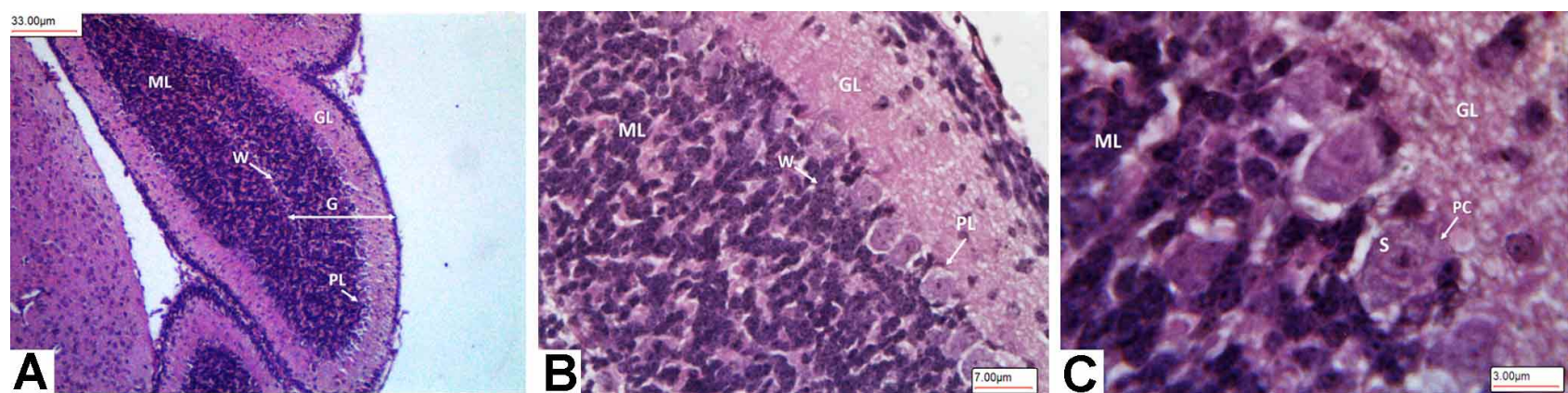

Fig. 1. Light microscopy image of Hematoxylin and Eosin (H\&E) stained cerebellum from the group one (control group). A. Showing the gray matter $(\mathrm{G})$, and white matter $(\mathrm{W})$. B. The grey matter consists of three layers which are the Purkinje cell layer (PL), the granular layer (GL), and the molecular layer (ML). C. Showing Neuron purkinjense consisting of cell body (S), dendrites and axon in the PL layer. The dendrite and axon cannot be viewed in this image due to the plane of sectioning. Mag. 100X, 400X and 1000X, respectively. 
AL-AMRI, I. S.; KADIM, I. T.; ALKINDI, A.; KHALAF, S. K.; HAMAED, A.; AL- YAQOOBI, S. S.; AL-HARRASI, A. S.; AL-HASHMI, S. A.; AL-MAASBI, A. A.; AL-HARTHY, R. S.; ALSHABIBI, A. S. \& AL-AMRI, A. I. Effects of prenatal tobacco smoke on cerebellum histomorphological changes at critical developmental stages in CD-1 mice. Int. J. Morphol., 39(1):318-326, 2021.

In the second group, which consists of mice with tobacco smoke exposure of two weeks, the tissues from the cerebellum showed representation of white matter and grey matter as shown in Figure 2. The general structural organization of the cerebellum tissue and morphological details appeared normal as shown in Figure 2. No damage was observed in the morphology of this tissue at this magnification. However, at higher magnifications, as shown in Figure 2, there appeared to be a small degree of damage in the PL layer. The Neuron purkinjense showed minor degrees of shrinkage to their soma shape as well as minor damage to their cytoplasm.
In group three, which consists of mice with tobacco smoke exposure of three weeks, the tissues from the cerebellum showed representation of white matter and grey matter as shown in Figure 3. The general structural organization and morphological details of the cerebellum tissue showed an increased damage to the PL as shown in Figures 3B, C and E. There appeared to be more damage observed in the PL layer than those observed in group two with decreased number of cells. The Neuron purkinjense showed a degree of shrinkage to their soma and the cytoplasmic intracellular material of Neuron purkinjense showed damage to their structures.
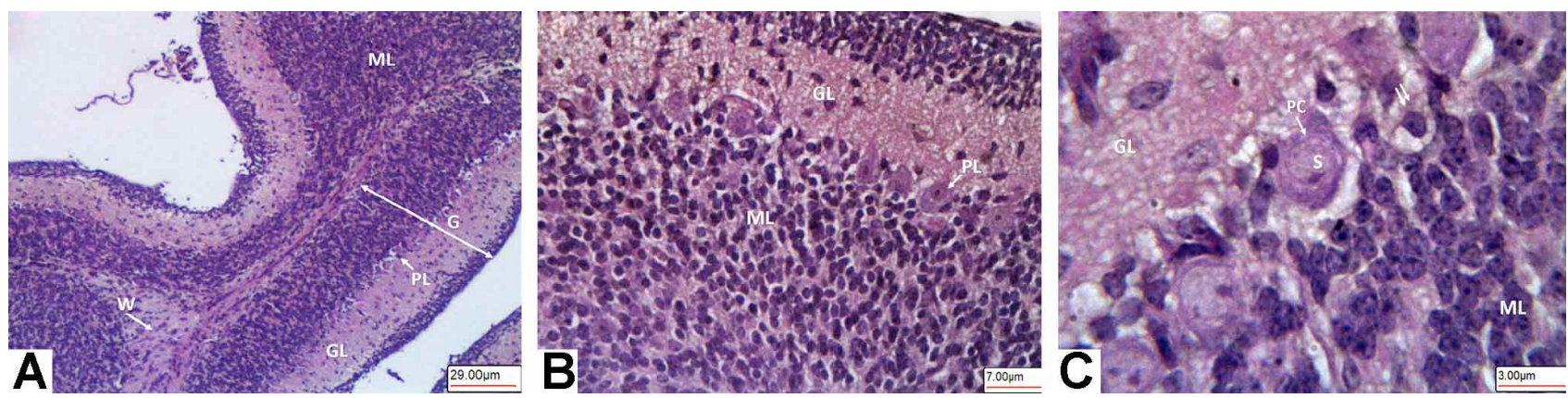

Fig. 2. Histology image of H\&E stained cerebellum from group two showing the gray matter (G), and white matter (W). A. Showing the gray matter $(\mathrm{G})$, and white matter (W). B. The gray matter consists of three layers which are the Purkinje cell layer (PL), the granular layer (GL), and the molecular layer (ML). C. Showing few Neuron purkinjense with soma appeared damaged and the cytoplasm lost intracellular materials (double arrow). Mag. 100X, 400X and 1000X, respectively.
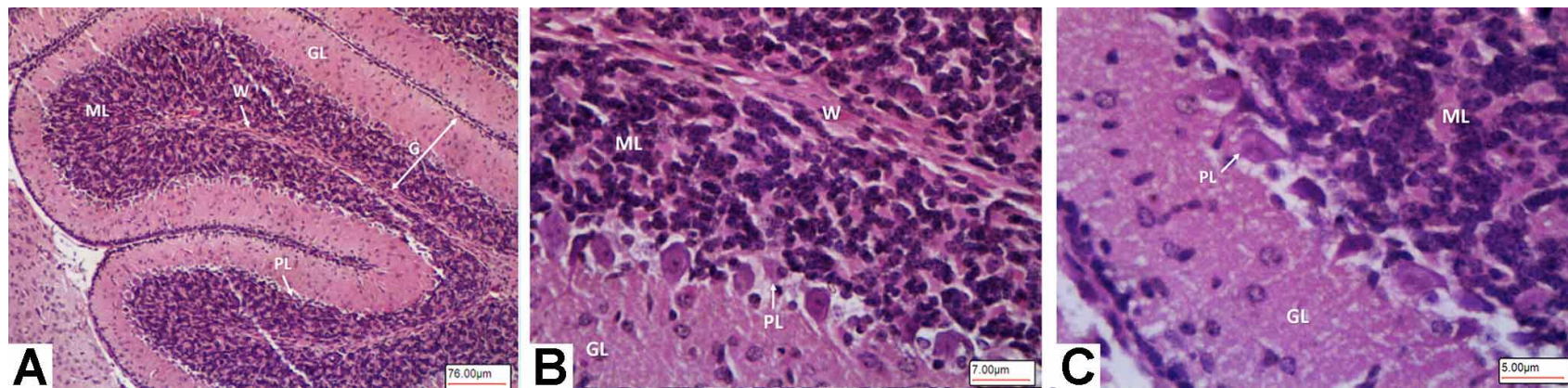

Fig. 3. Histology image of $H \& E$ stained cerebellum from group two showing the gray matter $(G)$, and white matter (W). A. Showing the gray matter $(\mathrm{G})$, and white matter (W). B and C. The gray matter consists of three layers which are the Purkinje cell layer (PL), the granular layer (GL), and the molecular layer (ML). D. Showing an increased number of Neuron purkinjense with damaged soma and the cytoplasm lost intracellular materials (double arrow). Mag. 40X, 400X, 600 and 1000X, respectively.

\section{DISCUSSION}

The cerebellum is a highly organized structure in which the Neuron purkinjense are the sole output of the cerebellar cortex (Altman, 1972a,b,c), and it is one of the first structures of the brain to differentiate. However, it achieves its mature configuration in few months after birth (Bouët et al., 2005). The cerebellum is considered vulnerable to developmental irregularities on exposure to toxics, which causes cellular dysfunction and in utero death or teratogenicity (Wang \& Zoghbi, 2001; Kern \& Jones, 2006; Imosemi).

The effect of tobacco smoking on cerebellum morphology changes was studied using mice models at critical developmental stages in juveniles. Three groups of 
AL-AMRI, I. S.; KADIM, I. T.; ALKINDI, A.; KHALAF, S. K.; HAMAED, A.; AL- YAQOOBI, S. S.; AL-HARRASI, A. S.; AL-HASHMI, S. A.; AL-MAASBI, A. A.; AL-HARTHY, R. S.; ALSHABIBI, A. S. \& AL-AMRI, A. I. Effects of prenatal tobacco smoke on cerebellum histomorphological changes at critical developmental stages in CD-1 mice. Int. J. Morphol., 39(1):318-326, 2021.

pregnant mice were housed in chambers and subjected to controlled environments under strict experimental conditions. The control group or group one received fresh air from the room, while group two received tobacco smoke for a two-week period with a two-hour dose per day. The third group received tobacco smoke for a three-week period and a dose of two-hour per day. Ten-day old mice juveniles were sacrificed, and the cerebellum tissue was examined for morphological changes. The general morphology of juvenile mice cerebellum from the control group showed a normal structure of white matter and grey matter. The grey matter located in the cortex consists of three layers: granular layer, Purkinje cell layer (PL) and molecular layer. The white matter located in the medulla consists mainly of neuroglia cells. The grey matter consists of nerve cells which includes neurons and neuroglia cells. The Neuron purkinjense (multipolar neurons) are in the Purkinje cell layer. The morphology of Neuron purkinjense in the gray matter appeared normal. The structure of the neurons consists of the cell body or soma, multiple dendrites and an axon. The soma appeared round with a large nucleus containing a single nucleolus in the center.

The second group, which received a daily dose of tobacco smoke of two hours of every two weeks, showed minor changes in the structure of Neuron purkinjense in the PL. The third group, however, which received a daily dose of tobacco smoke for three weeks, showed more damage to the morphology of the PL with fewer cells than those observed in group two. The structure of Neuron purkinjense appeared shrunken with damage observed to their cell body and the cytoplasm. The current results support the hypothesis of a close relation between maternal tobacco smoking during pregnancy and many abnormal processes in baby brain development. Lower total cerebral mass was detected in neonatal rats exposed to tobacco smoke. Histological changes were also observed in brain tissue such as impaired maturation of pyramidal neurons, reduction of the pyramidal area, and narrowing of the cortical layer (Lambers \& Clark, 1996). The histological changes in the structure of rat foetal brains subjected to the effects of smoke can be extrapolated to changes in humans. Relatively mild pre-natal exposure of mice to carbon monoxide, found in tobacco smoke, has been reported to alter certain biochemical and functional integrity in the central nervous system postnatal (Imosemi).

Such alterations include change in the content of some neurotransmitters in the brain stem and cerebellum (Storm \& Fechter, 1985; Storm et al., 1986). Matturri et al. (2006) reported that the morphological and functional changes of the foetus brainstem were associated with maternal smoking in $91 \%$ of the cases. Prenatal tobacco smoke had an effect on foetal carboxyl haemoglobin function causing a deficient in oxygen transfer which impairs the development of the nervous system (Matturri et al.: Król et al., 2012). Moreover, studies revealed that premature babies that were exposed to tobacco smoke in utero showed statistically significant reduction in the volume of the frontal lobes and cerebellum, (Ekblad et al., 2010). Volpe (2009) found that maternal smoking exposures affected cerebellar growth and development of the fetus.

Histological and ultrasound studies have also shown that maternal smoking has a harmful effect on prenatal cerebellar development by reducing cerebellar volumes in prematurely born infants of smoking mothers (Ekblad et al., 2010). In line with the present study, direct influences of maternal smoking have been demonstrated in animal studies reporting alterations in various receptors and cellular processes (Dwyer et al., 2009; Slotkin \& Seidler, 2011). Moreover, Storm \& Fechter and Storm et al. stated that the developing cerebellum is highly susceptible to prenatal chemical exposure at low concentration. Studies have shown that Neuron purkinjense are vulnerable to ischaenia, hypoxia, excitotoxicity, oxidative stress and exposure to different types of chemicals including tobacco chemicals (Kern \& Jones). It has been well documented that prenatal carbon monoxide exposure has selective effects on different brain cell types (Benagiano et al., 2005). Studies on human have only reported indirect evidence for harmful influences of tobacco smoke on behavioral and cognitive outcome in the offspring (Ernst et al., 2001). Numerous studies have shown that maternal smoking is associated with reduced head growth and total brain volume measured in the second half of pregnancy (Roza et al., 2007; Anblagan et al., 2013; Ekblad et al., 2015). Toxicity of tobacco may alter epigenetic mechanisms and vascular processes which may directly or indirectly affect cerebellar growth and maturation (Ekblad et al., 2015). In the current study, the daily exposure of pregnant mice to tobacco smoke caused a degree of damage to the tissues of cerebellum obtained from the 10-day juvenile mice.

The current findings are consistent with the results obtained by Layessi et al. (2004), which reported that tobacco cigarette smoke exposure in utero was correlated to the biological damage of the cerebellum. Moreover, the present findings endorsed other studies that reported that prenatal tobacco exposure may cause behavioral outcomes such as activity and inattention and externalizing behaviors, as well as conduct disorders which may be the results of morphology changes in the Neuron purkinjense.

In adolescents, prenatal tobacco exposure predicted increased attention deficit hyperactivity disorder, 
AL-AMRI, I. S.; KADIM, I. T.; ALKINDI, A.; KHALAF, S. K.; HAMAED, A.; AL- YAQOOBI, S. S.; AL-HARRASI, A. S.; AL-HASHMI, S. A.; AL-MAASBI, A. A.; AL-HARTHY, R. S.; ALSHABIBI, A. S. \& AL-AMRI, A. I. Effects of prenatal tobacco smoke on cerebellum histomorphological changes at critical developmental stages in CD-1 mice. Int. J. Morphol., 39(1):318-326, 2021.

modulation of the cerebral cortex and white matter structure, and nicotine addiction. Day et al. (2000) examined the relationship between prenatal tobacco exposure and the development of behavior problems in 672 children at three years of age. They found that there are significant effects of prenatal tobacco exposure on the children's behavior at age three. Increases in the oppositional behavior, immaturity, emotional instability, physical aggression, and activity in infants were highly correlated to prenatal tobacco exposure. Prenatal tobacco exposure was associated with lower birth weight, increased rates of disruptive behavior disorders, and substance use disorders as well as decreased rates of mood disorders (Talati et al., 2017). The later authors concluded that maternal smoking has long term adverse consequences for offspring.

The results of meta-analysis based on 20 observational studies with a total of 50044 cases and 2998059 participants revealed that prenatal tobacco smoking was associated with a $60 \%$ increase in odds of attention-deficit/hyperactivity disorder in babies (Huang et al., 2018). Attention-deficit/hyperactivity disorder is a common neurodevelopmental disorder which is characterized by inattention, impulsivity, and/or hyperactive or impulsive behaviors and often persists into adulthood, with worldwide prevalence estimates ranging from $3 \%$ to $10 \%$ of school aged children (Faraone \& Doyle, 2001; Linnet et al., 2003; Rommelse et al., 2011). Research findings on the effects of prenatal exposure on internalizing disorders and their association with anxiety and depression (Hettema et al., 2005; Ashford et al., 2008; Carter et al., 2008; Robinson et al., 2010; Moylan et al., 2015; Talati et al., 2017).

According to Kristjansson et al. (2018), children whose mothers smoke during the first trimester of pregnancy are at greater risk for poor scholastic outcomes than children whose mothers do not smoke during their first trimester. All of these abnormalities may have serious consequences, such as pulmonary development, which may be associated with shrunken Neuron purkinjense along with damage in cell body and the cytoplasm. Tobacco components can cross the placenta and reach higher levels in the fetus than in the smoker mother (Lambers \& Clark; Rogers 2009).

The present study supports the correlation between exposures to tobacco components and brain development, which includes both serotonergic, and dopaminergic neurons and stimulation of the brain receptors during pregnancy which might change their sensitivity, leading to impaired neural growth and circuit formation (Ernst et al.; Slotkin et al., 2006). These deficits may be observed in the infant stage of life, childhood and adolescence, once brain circuits regulating behavioral control have matured (Wakschlag et al., 2002; Baler et al., 2008). Furthermore, Studies have provided evidence of associations between prenatal tobacco exposure and offspring neurodevelopmental and behavioral problems (Huizink \& Mulder, 2006; Knopik, 2009; D'Onofrio et al., 2013), bipolar disorder (Talati et al., 2013; Quinn et al., 2017), schizophrenia (Niemelä et al., 2016; Quinn et al.) and related outcomes (Mackay et al., 2017). These associations increase the possibility that prenatal tobacco exposure may increase the risk of severe mental illnesses (Debnath et al., 2015). Because nicotine and carbon monoxide cross the placenta and may directly and indirectly affect fetal neurodevelopment (Ekblad et al., 2015), there is extensive and clear evidence that exposure to prenatal smoke has severe adverse consequences on the fetus (Laursen \& McGrath, 2016).

\section{CONCLUSION}

This study assessed the effects of prenatal tobacco smoking on cerebellum histo-morphological changes at critical developmental stages in pregnant mice. The histological results showed damage in the structure of Neuron purkinjense in juvenile mice in the prenatal tobacco smoking group. The results confirmed that tobacco exposure in pregnant mice may affect neurodevelopment which in turn may induce behavioural change as a result of reduced cerebellar size and function which lead to attention deficit hyperactivity disorder and conduct disorders. Therefore, pregnant women should be warned that smoking may place their unborn children at a high risk of a variety of morphological damage to the cerebellum that can lead to brain damage. Active smoking during pregnancy may reduce the cerebral mass of neonates and cause severe damage in Neuron purkinjense of cerebellum.

FUNDING. This work was supported by the grant of the Research Council of Oman.

\section{ACKNOWLEDGMENT}

We would like to thank Dr. Wameath Abdul-Majeed and Ms Asiya Al-Hooti from College of Engineering for their technical assistance with the smoking exposure system. Also, thankful goes to Dr. Fatema Jamshidi-Adegani, Mr. Saeid Vakilian, and Mr. Syed Farooq from the Natural and Medical Sciences Research Center for their technical assistance with tissue sampling. 
AL-AMRI, I. S.; KADIM, I. T.; ALKINDI, A.; KHALAF, S. K.; HAMAED, A.; AL- YAQOOBI, S. S.; AL-HARRASI, A. S.; AL-HASHMI, S. A.; AL-MAASBI, A. A.; AL-HARTHY, R. S.; AL-SHABIBI, A. S. \& AL-AMRI, A. I. Efectos del humo de tabaco en los cambios histomorfológicos del cerebelo en las etapas críticas del desarrollo prenatal en ratones CD-1. Int. J. Morphol.,39(1):318-326, 2021.

RESUMEN: Se evaluaron los efectos producidos por la exposición prenatal al humo de tabaco en ratones expuestos y no expuestos y los cambios histomorfológicos observados en el cerebelo en ambos grupos. Un total de 30 ratones cd-1 preñados se dividieron en tres grupos de 10 ratones cada uno y con dos réplicas por grupo (5 ratones cada uno). Después de la aclimatación durante cinco días, los ratones se colocaron en una máquina de fumar modificada, especial durante 2 horas al día, durante un período de dos y tres semanas para el grupo dos y el grupo tres, respectivamente. El grupo uno se consideró como grupo control. Los ratones del grupo de control fueron expuestos simultáneamente al aire limpio de la habitación, mientras que los grupos de tratamiento fueron expuestos al humo de tabaco de seis cigarrillos comerciales, que contenían $0,8 \mathrm{mg}$ de nicotina, $10 \mathrm{mg}$ de alquitrán y $10 \mathrm{mg}$ de monóxido de carbono. durante tres períodos de 1 hora diariamente, durante tres semanas. Los ratones del grupo de control se expusieron al aire ambiente durante tres períodos de 1 hora todos los días durante el mismo período de tres semanas. Los resultados de este estudio mostraron una correlación entre el tabaquismo materno y los cambios histológicos en las neuronas purkinjenses (células de Purkinje). Se observó además que el período de tabaquismo prenatal puede haber causado mayor daño en la histología y estructura de las neuronas purkinjenses en algunos ratones jóvenes. También se observó una mayor incidencia de daño morfológico de las estructuras de las neuronas purkinjenses del cerebelo en fetos con exposición prolongada al tabaquismo. La exposición al tabaquismo materno en el útero puede interferir con los parámetros de desarrollo biológico del cerebro, dando lugar a anomalías estructurales del cerebelo. Este estudio concluyó que la exposición al humo del tabaco en ratones preñados puede afectar el desarrollo neurológico, lo que puede inducir cambios de comportamiento como resultado de la reducción del tamaño y la función del cerebelo.

PALABRAS CLAVE: Humo de tabaco prenatal; Cerebelo; Histomorfología; Ratones CD-1; Células de Purkinje; Neuronas purkinjenses; Juvenil.

\section{REFERENCES}

Altman, J. \& Bayer, S. A. Time of origin and distribution of a new cell type in the rat cerebellar cortex. Exp. Brain Res., 29(2):265-74, 1978.

Altman, J. \& Winfree, A. T. Postnatal development of the cerebellar cortex in the rat. V. Spatial organization of purkinje cell perikarya. J. Comp. Neurol., 171(1):1-16, 1977.

Altman, J. Postnatal development of the cerebellar cortex in the rat. I. The external germinal layer and the transitional molecular layer. J. Comp. Neurol., 145(3):353-97, 1972a.

Altman, J. Postnatal development of the cerebellar cortex in the rat. II. Phases in the maturation of Purkinje cells and of the molecular layer. $J$. Comp. Neurol., 145(4):399-464, 1972b.
Altman, J. Postnatal development of the cerebellar cortex in the rat. 3 . Maturation of the components of the granular layer. J. Comp. Neurol., 145(4):465-513, 1972c.

Anblagan, D.; Jones, N. W.; Costigan, C.; Parker, A. J. J.; Allcock, K.; Aleong, R.; Coyne, L. H.; Deshpande, R.; Raine-Fenning, N.; Bugg, $\mathrm{G}$.; et al. Maternal smoking during pregnancy and fetal organ growth: a magnetic resonance imaging study. PLoS One, 8(7):e67223, 2013.

Ashford, J.; van Lier, P. A. C.; Timmermans, M.; Cuijpers, P. \& Koot, H. M. Prenatal smoking and internalizing and externalizing problems in children studied from childhood to late adolescence. J. Am. Acad. Child Adolesc. Psychiatry, 47(7):779-87, 2008.

Baler, R. D.; Volkow, N. D.; Fowler, J. S. \& Benveniste, H. Is fetal brain monoamine oxidase inhibition the missing link between maternal smoking and conduct disorders? J. Psychiatry Neurosci., 33(3):187-95, 2008 .

Benagiano, V.; Lorusso, L.; Coluccia, A.; Tarullo, A.; Flace, P.; Girolamo, F.; Bosco, L.; Cagiano, R. \& Ambrosi, G. Glutamic acid decarboxylase and GABA immunoreactivities in the cerebellar cortex of adult rat after prenatal exposure to a low concentration of carbon monoxide. Neuroscience, 135(3):897-905, 2005.

Benowitz, N. Z.; Hall, S. M.; Stewart, S.; Wilson, D.; Dempsey, P. J. \& Jacob 3rd, P. Nicotine and carcinogen exposure with smoking of progressively reduced nicotine content cigarette. Cancer Epidemiol. Biomarkers Prev., 16(11):2479-85, 2007.

Bhutta, Z. A.; Lassi, Z. S.; Blanc, A. \& Donnay, F. Linkages among reproductive health, maternal health, and perinatal outcomes. Semin. Perinatol., 34(6):434-45, 2010.

Bouët, V.; Dijk, F.; Ijkema-Paassen, J.; Wubbels, R.J .; van der Want, J. J. \& Gramsbergen, A. Early hypergravity exposure effects calbindin-D28k and inositol-3-phosphate expression in Purkinje cells. Neurosci. Lett., 382(1-2):10-5, 2005.

Carter, S.; Paterson, J.; Gao, W. \& Iusitini, L. Maternal smoking during pregnancy and behaviour problems in a birth cohort of 2-year-old Pacific children in New Zealand. Earl Hum. Develop., 84(1):59-66, 2008.

Chang, C. H.; Chang, F. M.; Yu, C. H.; Ko, H. C. \& Chen, H. Y. Assessment of fetal cerebellar volume using three-dimensional ultrasound. Ultrasound Med. Biol., 26(6):981-8, 2000.

Cornelius, M. D. \& Day, N. L. Developmental consequences of prenatal tobacco exposure. Curr. Opin. Neurol., 22(2):121-5, 2009.

Crepel, F. Maturation of climbing fiber responses in the rat. Brain Res., 35(1):272-6, 1971.

D’Onofrio, B. M.; Lahey, B. B.; Turkheimer, E. \& Lichtenstein, P. Critical need for family-based, quasi-experimental designs in integrating genetic and social science research. Am. J. Public Health, 103 Suppl. 1(Suppl. 1):S46-55, 2013.

Day, N. L.; Richardson, G. A.; Goldschmidt, L. \& Cornelius, M. D. Effects of prenatal tobacco exposure on preschoolers' behavior. J. Dev. Behav. Pediatr., 21(3):180-8, 2000

Debnath, M.; Venkatasubramanian, G. \& Berk, M. Fetal programming of schizophrenia: select mechanisms. Neurosci. Biobehav. Rev., 49:90104, 2015.

Dwyer, J. B.; McQuown, S. C. \& Leslie, F. M. The dynamic effects of nicotine on the developing brain. Pharmacol. Ther, 122(2):125-39, 2009.

Ekblad, M.; Korkeila, J. \& Lehtonen, L. Smoking during pregnancy affects foetal brain development. Acta Paediatr., 104(1):12-8, 2015.

Ekblad, M.; Korkeila, J.; Parkkola, R.; Lapinleimu, H.; Haataja, L.; Lehtonen, L. \& PIPARI Study Group. Maternal smoking during pregnancy and regional brain volumes in preterm infants. J. Pediatr., 156(2):185-90.e1, 2010.

Ernst, M.; Moolchan, E. T. \& Robinson, M. L. Behavioral and neural consequences of prenatal exposure to nicotine. J. Am. Acad. Child Adolesc. Psychiatry, 40(6):630-41, 2001.

Erzen, I. \& Kragelj, L. Z. Cadmium concentrations in blood in a group of male recruits in Slovenia related to smoking habits. Bull. Environ. Contam. Toxicol., 76(2):278-84, 2006. 
Faraone, S. V. \& Doyle, A. E. The nature and heritability of attention-deficit/ hyperactivity disorder. Child Adolesc. Psychiatr. Clin. N. Am., 10(2):299-316, 2001.

Fowles, J. \& Dybing, E. Application of toxicological risk assessment principles to the chemical constituents of cigarette smoke. Tobacco Cont., 12(4):424-30, 2003.

Fuller, B. F.; Gold, M. S.; Wang, K. K. W. \& Ottens, A. K. Effects of environmental tobacco smoke on adult rat brain biochemistry. J. Mol. Neurosci., 41(1):165-71, 2010.

Galazyn-Sidorczuk, M.; Brzóska, M. M. \& Moniuszko-Jakoniuk, J. Estimation of Polish cigarettes contamination with cadmium and lead, and exposure to these metals via smoking. Environ. Monit. Assess., 137(1-3):481-93, 2008.

Hecht, S. S.; Murphy, S. E.; Carmella, S. G.; Li, L.; Jensen, J.; Le, C.; Joseph, A. M. \& Hatsukami, D. K. Similar uptake of lung carcinogens by smokers of regular, light, and ultralight cigarettes. Cancer Epidemiol. Biomarkers Prev., 14(3):693-8, 2005.

Hendelman, W. J. Atlas of Functional Neuroanatomy. Boca Ratón, CRC Press LLC, 2000. pp.126-34.

Hettema, J. M.; Prescott, C. A.; Myers, J. M.; Neale, M. C. \& Kendler, K. $\mathrm{S}$. The structure of genetic and environmental risk factors for anxiety disorders in men and women. Arch. Gen. Psychiatry, 62(2):182-9, 2005.

Huang, L.; Wang, Y.; Zhang, L.; Zheng, Z.; Zhu, T.; Qu, Y. \& Mu, D. Maternal smoking and attention-deficit/hyperactivity disorder in offspring: a meta-analysis. Pediatrics, 141(1):e20172465, 2018.

Huizink, A. C. \& Mulder, E. J. H. Maternal smoking, drinking or cannabis use during pregnancy and neurobehavioral and cognitive functioning in human offspring. Neurosci. Biobehav. Rev., 30(1):24-41, 2006.

Imosemi, I. O. The role of antioxidants in cerebellar development: a review of literature. Int. J. Morphol., 31(1):203-10, 2013.

Kern, J. K. \& Jones, A. M. Evidence of toxicity, oxidative stress, and neuronal insult in autism. J. Toxicol. Environ. Health B. Crit. Rev., 9(6):485-99, 2006.

Knopik, V. S. Maternal smoking during pregnancy and child outcomes: Real or spurious effect? Dev. Neuropsychol., 34(1):1-36, 2009.

Kristjansson, A. L.; Thomas, S.; Lilly, C. L.; Thorisdottir, I. E.; Allegrante, J. P. \& Sigfusdottir, I. D. Maternal smoking during pregnancy and academic achievement of offspring over time: A registry data-based cohort study. Prev. Med., 113:74-9, 2018.

Król, M.; Florek, E.; Piekoszewski, W.; Bokiniec, R. \& Kornacka, M. K. The impact of intrauterine tobacco exposure on the cerebral mass of the neonate based on the measurement of head circumference. Brain Behav., 2(3):243-8. 2012.

Lambers, D. S. \& Clark, K. E. The maternal and fetal physiologic effects of nicotine. Semin. Perinatol., 20(2):115-26, 1996.

Laursen, T. M. \& McGrath, J. J. The strange case of smoking and schizophrenia-The epidemiology detectives are on the trail. Am. J. Psychiatry, 173(8):757-8, 2016.

Limperopoulos, C.; Soul, J. S.; Gauvreau, K.; Huppi, P. S.; Warfield, S. K.; Bassan, H.; Robertson, R. L.; Volpe, J. J. \& du Plessis, A. J. Late gestation cerebellar growth is rapid and impeded by premature birth. Pediatrics, 115(3):688-95, 2005.

Linnet, K. M.; Dalsgaard, S.; Obel, C.; Wisborg, K.; Henriksen, T. B.; Rodriguez, A.; Kotimaa, A.; Moilanen, I.; Thomsen, P. H.; Olsen, J.; et al. Maternal lifestyle factors in pregnancy risk of attention deficit hyperactivity disorder and associated behaviors: review of the current evidence. Am. J. Psychiatry, 160(6):1028-40, 2003.

Mackay, D. F.; Anderson, J. J.; Pell, J. P.; Zammit, S. \& Smith, D. J. Exposure to tobacco smoke in utero or during early childhood and risk of hypomania: Prospective birth cohort study. Eur. Psychiatry, 39:33-9, 2017.

Mariani, J. Extent of multiple innervation of Purkinje cells by climbing fibers in the olivocerebellar system of weaver, reeler, and staggerer mutant mice. J. Neurobiol., 13(2):119-206, 1982.

Massadeh, A. M.; Alali, F. Q. \& Jaradat, Q. M. Determination of cadmium and lead in different cigarette brands in Jordan. Environ. Monit. Assess., 104(1-3):163-70, 2005.
Matturri, L.; Ottaviani, G. \& Lavezzi, A. M. Maternal smoking and sudden infant death syndrome: epidemiological study related to pathology. Virchows Arch., 449(6):697-706, 2006.

Moylan, S.; Gustavson, K.; Øverland, S.; Karevold, E. B.; Jacka, F. N.; Pasco, J. A. \& Berk, M. The impact of maternal smoking during pregnancy on depressive and anxiety behaviors in children: the Norwegian Mother and Child Cohort Study. BMC Med., 13:24, 2015.

Musk, A. W. \& de Klerk, N. H. History of tobacco and health. Respirology, 8(3):286-90, 2003.

Niemelä, S.; Sourander, A.; Surcel, H. M.; Hinkka-Yli-Salomäki, S.; McKeague, I. W.; Cheslack-Postava, K. \& Brown, A. S. Prenatal nicotine exposure and risk of schizophrenia among offspring in a national birth cohort. Am. J. Psychiatry, 173(8):799-806, 2016.

Pappas, R. S.; Polzin, G. M.; Watson, C. H. \& Ashley, D. L. Cadmium, lead, and thallium in smoke particulate from counterfeit cigarettes compared to authentic US brands. Food Chem. Toxicol., 45(2):202-9, 2007.

Quinn, P. D.; Rickert, M. E.; Weibull, C. E.; Johansson, A. L. V.; Lichtenstein, P.; Almqvist, C.; Larsson, H.; Iliadou, A. N. \& D’Onofrio, B. M. Association between maternal smoking during pregnancy and severe mental illness in offspring. JAMA Psychiatry, 74(6):589-96, 2017.

Robinson, M.; McLean, N. J.; Oddy, W. H.; Mattes, E.; Bulsara, M.; Li, J.; Zubrick, S. R.; Stanley, F. J. \& Newnham, J. P. Smoking cessation in pregnancy and the risk of child behavioural problems: a longitudinal prospective cohort study. J. Epidemiol. Community Health, 64(7):622-9, 2010.

Rommelse, N. N. J.; Geurts, H. M.; Franke, B.; Buitelaar, J. K. \& Hartman, C. A. A review on cognitive and brain endophenotypes that may be common in autism spectrum disorder and attention-deficit/hyperactivity disorder and facilitate the search for pleiotropic genes. Neurosci. Biobehav. Rev., 35(6):1363-96, 2011.

Roza, S. J.; Verburg, B. O.; Jaddoe, V. W. V.; Hofman, A.; Mackenbach, J. P.; Steegers, E. A. P.; Witteman, J. C. M.; Verhulst, F. C. \& Tiemeier, $\mathrm{H}$. Effects of maternal smoking in pregnancy on prenatal brain development. The Generation R Study. Eur. J. Neurosci., 25(3):611-7, 2007.

Shevelkin, A. V.; Ihenatu, C. \& Pletnikov, M. V. Pre-clinical models of neurodevelopmental disorders: focus on the cerebellum. Rev. Neurosci., 25(2): 177-94, 3014.

Slotkin, T. A. \& Seidler, F. J. Mimicking maternal smoking and pharmacotherapy of preterm labor: Fetal nicotine exposure enhances the effect of late gestational dexamethasone treatment on noradrenergic circuits. Brain Res. Bull., 86(5-6):435-40, 2011.

Slotkin, T. A.; Tate, C. A.; Cousins, M. M. \& Seidler, F. J. Prenatal nicotine exposure alters the responses to subsequent nicotine administration and withdrawal in adolescence: Serotonin receptors and cell signaling. Neuropsychopharmacology, 31(11):2462-75, 2006.

Stepanov, I.; Jensen, J.; Hatsukami, D. \& Hecht, S. S. New and traditional smokeless tobacco: comparison of toxicant and carcinogen levels. Nicotine Tob. Res., 10(12):1773-82, 2008.

Steyn, K.; de Wet, T.; Saloojee, Y.; Nel, H. \& Yach, D. The influence of maternal cigarette smoking, snuff use and passive smoking on pregnancy outcomes: the Birth To Ten Study. Paediatr. Perinat. Epidemiol., 20(2):90-9, 2006.

Stolerman, I. P. \& Jarvis, M. J. The scientific case that nicotine is addictive. Psychopharmacology (Berl.), 117(1):2-10, 1995.

Storm, J. E. \& Fechter, L. D. Alteration in the postnatal ontogeny of cerebellar norepinephrine content following chronic prenatal carbon monoxide. J. Neurochem., 45(3):965-9, 1985.

Storm, J. E.; Valdes, J. J. \& Fechter, L. D. Postnatal alterations in cerebellar GABA content, GABA uptake and morphology following exposure to carbon monoxide early in development. Dev. Neurosci., 8(4):251-61, 1986.

Talati, A.; Bao, Y.; Kaufman, J.; Shen, L.; Schaefer, C. A. \& Brown, A. S. Maternal smoking during pregnancy and bipolar disorder in offspring. Am. J. Psychiatry, 170(10):1178-85, 2013. 
AL-AMRI, I. S.; KADIM, I. T.; ALKINDI, A.; KHALAF, S. K.; HAMAED, A.; AL- YAQOOBI, S. S.; AL-HARRASI, A. S.; AL-HASHMI, S. A.; AL-MAASBI, A. A.; AL-HARTHY, R. S.; ALSHABIBI, A. S. \& AL-AMRI, A. I. Effects of prenatal tobacco smoke on cerebellum histomorphological changes at critical developmental stages in CD-1 mice. Int. J. Morphol., 39(1):318-326, 2021.

Talati, A.; Wickramaratne, P. J.; Wesselhoeft, R. \& Weissman, M. M. Prenatal tobacco exposure, birthweight, and offspring psychopathology. Psychiatry Res., 252:346-52, 2017.

ten Donkelaar, H. J.; Lammens, M.; Wesseling, P.; Thijssen, H. O. M. \& Renier, W. O. Development and developmental disorders of the human cerebellum. J. Neurol., 250(9):1025-36, 2003.

Viana, G. F. S.; Garcia, K. S. \& Menezes-Filho, J. A. Assessment of carcinogenic heavy metal levels in Brazilian cigarettes. Environ. Monit. Assess., 181(1-4):255-65, 2011.

Volpe, J. J. Cerebellum of the premature infant: rapidly developing, vulnerable, clinically important. J. Child. Neurol., 24(9):1085-104, 2009.

Wakschlag, L. S.; Pickett, K. E.; Cook Jr., E.; Benowitz, N. L. \& Leventhal, B. L. Maternal smoking during pregnancy and severe antisocial behavior in offspring: a review. Am. J. Public Health, 92(6):966-74, 2002.

Wang, V. Y. \& Zoghbi, H. Y. Genetic regulation of cerebellar development. Nat. Rev. Neurosci., 2(7):484-91, 2001.
Corresponding author:

Isam T. Kadim

Department of Biological Sciences and Chemistry

College of Arts and Sciences

University of Nizwa

PO Box 33, PC 616

Birkat Al-Mouz

Nizwa

OMAN

Email: isam@unizwa.edu.om

Received: 07-08-2020

Accepted: 09-09-2020 